\title{
Yoga Ocular Exercises to Maintain Eye Health During Work and Distance Learning in the New Normal Era
}

\author{
Ayunda Puteri Rizanti ${ }^{1}$ \\ ${ }^{1}$ Program Studi Keperawatan Universitas Jember, 68121, Jawa Timur, Indonesia. \\ *Korespondensi : ayundaputerir@gmail.com
}

\begin{abstract}
Abstrak: Pandemi COVID-19 menjadi tantangan dalam dunia kerja dan pendidikan karena diharuskan mengubah segala aktivitas dari tatap muka menjadi sistem jarak jauh dengan sistem online berbasis internet dan teknologi. Aktivitas online ini menyebabkan peningkatan eksposur dari layar digital seperti komputer dan ponsel di masyarakat. Menatap layar digital seringkali membuat mata kita bekerja lebih keras, tuntutan visual yang tinggi dari tampilan layar digital ini membuat mata menjadi rentan terhadap berbagai gejala yang mengarah pada masalah penglihatan. Artikel ini bertujuan untuk mengetahui pengaruh latihan yoga okuler terhadap eye fatigue (kelelahan mata) dan peningkatan kesehatan mata. Metode yang digunakan adalah studi literatur yang berfokus pada intervensi yoga okuler dalam mengatasi kelelahan mata dan memelihara kesehatan mata dengan database berupa PubMed, Wiley, Proquest dan Google Scholar diterbitkan pada 2015-2020. Melalui review terhadap 8 artikel terpilih, didapatkan hasil bahwa latihan yoga okuler memberikan manfaat berupa mengurangi kelelahan mata, merilekskan pikiran, mencegah gejala astenopia, meningkatkan fungsi penglihatan binokuler dengan meningkatkan efisiensi otot motilitas mata, dan juga mengurangi tekanan intraokular pada pasien glaukoma. Melalui review tersebut terlihat bahwa latihan yoga okuler dapat mencegah gangguan penglihatan dan menjaga kesehatan mata di masa new normal.
\end{abstract}

Kata kunci: Eye Fatigue, Yoga okuler, Kesehatan mata, New normal, Sistem daring

\begin{abstract}
The COVID-19 pandemic is a challenge for the world of work and education to change all activities from face-to-face systems into remote systems with internet and technology-based online systems. These online activities lead to increased exposure from digital screens such as computers and mobile phones in society. Viewing a computer or digital screen often makes our eyes work harder, this high visual demand of digital screen display makes many people susceptible to the development of vision-related symptoms. This article aims to determine the effect of yoga ocular exercises on eye fatigue and increase eye health The method we used was a literature study that focused on yoga ocular interventions in overcoming eye fatigue with databases in the form of PubMed, Willey, Proquest, NCBI and, Google Scholar published in 2015-2020. Through a review of 8 selected articles, the results showed that yoga ocular practice provides benefits in the form of reduce eye fatigue, relax the mind, prevent asthenopia symptoms, improve binocular vision function by increasing the efficiency of eye motility muscles, and also reduce the intraocular pressure in glaucoma patients. Through the review, it can be seen that yoga ocular practice can prevent vision problems and maintain eye health in the new normal era
\end{abstract}

Keywords: Eye fatigue, Yoga ocular, eye health, New normal, remote system 


\section{INTRODUCTION}

The COVID-19 pandemic has changed many things that affect all activities carried out by humans, one of which is replacing human contact with electronic connections. The emergence of the COVID - 19 pandemic and the worldwide lockdown was immediately followed by a drastic increase in the amount of time spent on these gadgets. Increasing the use of electronic devices (e-devices) and its effect on user welfare is a concern of health practitioners (Balasopoulos et al., 2017a).

Without specific guidelines, online learning and work processes become routine for children and adults to spend most of the time (8-12 hours per day) attending e-classes, meetings, and other work in front of computers or mobile screens (Munsamy \& Chetty, 2020). According to the American Optometric Association, as little as two hours of continuous digital device usage per day is enough to bring about the development of an array of eye and vision related problems, and is referred to as digital eye strain (Balasopoulou et al., 2017a,b).

Electronic devices also cause damage by emitting high-energy short-wave currents that can penetrate the eye and can eventually contribute to photochemical damage to retinal cells, making a person susceptible to a variety of eye problems ranging from dry eye to eye fatigue to age-related macular degeneration (Munsamy \& Chetty, 2020). Eye fatigue causes clinical manifestations include throbbing or pain around the eye and behind the eyeball, vision double, blurred vision, difficulty in focusing vision, sore eyes, redness, sore and watery eyes, headache, sometimes accompanied by nausea, aches and easy emotions (Novia, 2018)

The Prevention of Blindness (IAPB) and WHO stated that in 2018 an estimated 188.5 million people in the world have mild visual impairment, 217 million have moderate to severe visual impairment, and 36 million people with blindness. In Indonesia, due to visual disturbances refractive error which is its prevalence at $22.1 \%$, it becomes a problem that must be addressed immediately. About $10 \%$ of 66 million children of school age (5-19 years) suffer from refractive errors (Puspa, Loebis, \& Nuswantoro, 2018).

Ocular Yoga has great potential in being a solution to eye health problems, ocular yoga has advantages over other interventions such as being more affordable, easy to do, can be practiced independently, does not require a special place, and is an effort to prevent and improve eye health during remote system in COVID-19 pandemic (Sheikh, Malavde, \& Daigavane, 2020). Eye Yoga is an intervention to reduce fatigue eyes, it has physical as well as mental health benefits through down-regulation of action pituitary-adrenal and sympathetic nervous system (Kim, 2016). Eye Yoga practice can increase the sensitivity of visual perception and the ability to distinguish stimuli, eye exercises can make the eye muscles and their surroundings elastic and strong, reducing tension in the eye and can sharpen vision (Anwari et al., 2018). Based on this description, the purpose of this study was to determine the effect of eye yoga exercises on eye fatigue due to the increased length of time using gadgets during the new normal era in COVID-19 pandemic.

\section{METHOD}

This literature search uses searching methods from journals or original research, databases in the form of PubMed, Willey, Proquest and Google Scholar that relates to Yoga Ocular Exercise and it function for maintain eye health during work and distance learning using keywords: eye fatigue, yoga ocular, COVID-19, distance learning. There are inclusion and exclusion criteria in the literature used. The inclusion criteria used are: (1) Journals published in 2015-2020, (2) Journals in English and Indonesian (3) using yoga ocular exercise intervention (4) eye health output (while the exclusion criteria used are: (1) not only using yoga ocular for intervention (2) not focused on eye problems 

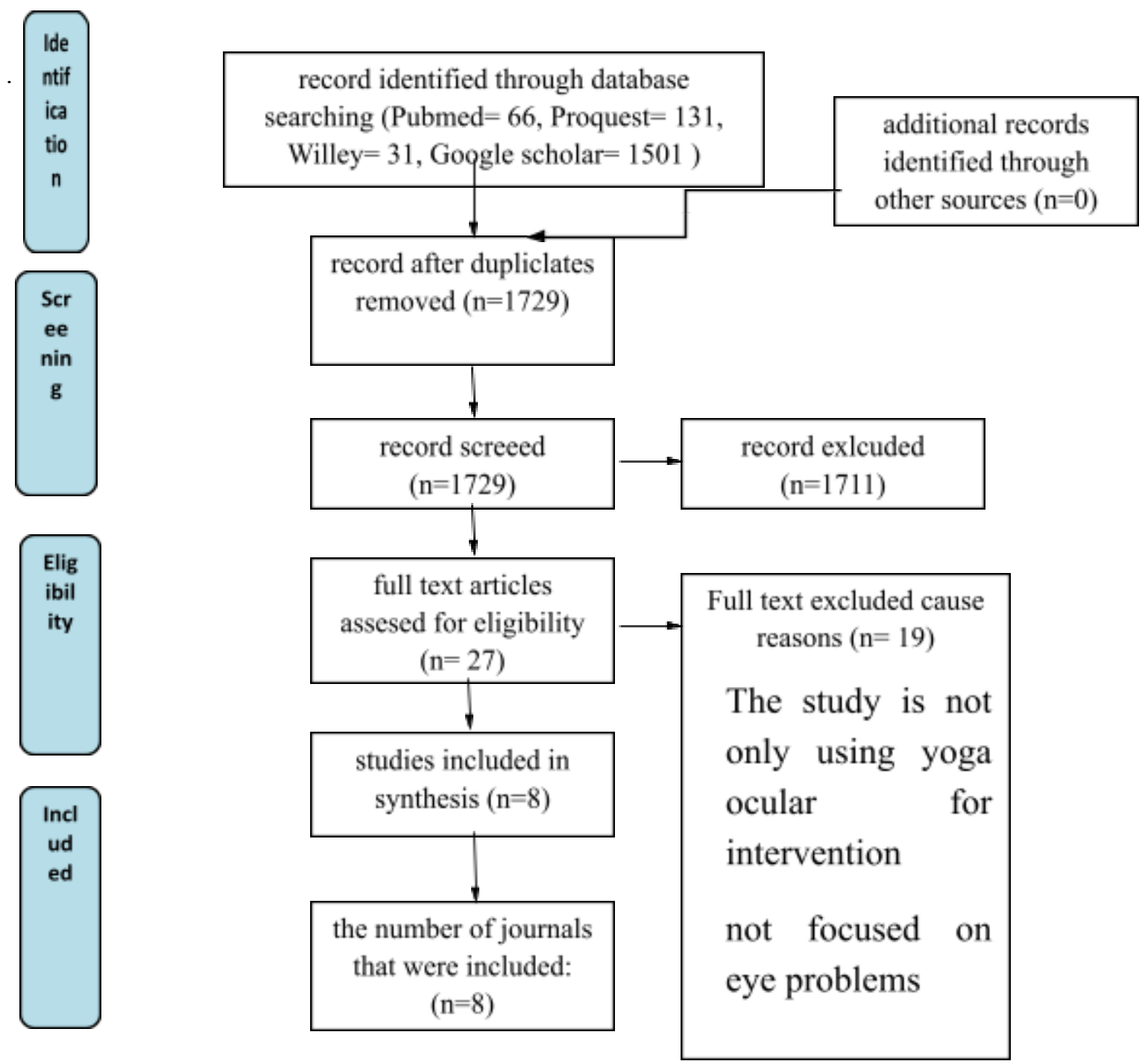

Figure 1. Study diagram using PRISMA Guideline

\section{RESULT}

A total of 8 articles were reviewed based on the following article search results:

Table 1. Literature studies

\begin{tabular}{|c|c|c|c|c|c|}
\hline Author & Year & Title & Method & Intervention & Result \\
\hline $\begin{array}{l}\text { Satish } \\
\text { Kumar } \\
\text { Gupta, } \\
\text { B.Optom, } \\
\text { Aparna } \\
\text { S,M. Phil }\end{array}$ & 2019 & $\begin{array}{l}\text { Effect of Yoga } \\
\text { Ocular } \\
\text { Exercises on } \\
\text { Binocular } \\
\text { Vision } \\
\text { Functions }\end{array}$ & $\begin{array}{l}\text { two groups } \\
\text { experimenta } \\
1 \text { design }\end{array}$ & $\begin{array}{l}\text { yoga ocular } \\
\text { exercises involved } \\
\text { the following } 10 \\
\text { steps in a sequence } \\
\text { for } 30 \text { minutes an } \\
\text { average of } 5 \\
\text { days/week. }\end{array}$ & $\begin{array}{l}\text { Yoga ocular } \\
\text { exercises improve } \\
\text { vergence and are } \\
\text { considered as a } \\
\text { therapeutic and } \\
\text { non-pharmacologic } \\
\text { al intervention for } \\
\text { improving } \\
\text { Vergence - related }\end{array}$ \\
\hline
\end{tabular}




\begin{tabular}{|c|c|c|c|c|c|}
\hline & & & & & $\begin{array}{l}\text { binocular vision } \\
\text { function. }\end{array}$ \\
\hline $\begin{array}{l}\text { Galina } \\
\text { Dimitrova } \\
\text { and Ana } \\
\text { Trenceva }\end{array}$ & 2015 & $\begin{array}{l}\text { The } \\
\text { short-term } \\
\text { effect of yoga } \\
\text { ocular } \\
\text { exercise on } \\
\text { intra-ocular } \\
\text { pressure }\end{array}$ & $\begin{array}{l}\text { two groups } \\
\text { experimenta } \\
1 \text { design }\end{array}$ & $\begin{array}{l}\text { procedure lasted } 5 \\
\text { min and consisted } \\
\text { of a short } \\
\text { relaxa-tion } \\
\text { technique, } \\
\text { including slow and } \\
\text { continuous } \\
\text { movements and } \\
\text { stretching of the } \\
\text { bulbomotor } \\
\text { muscles. }\end{array}$ & $\begin{array}{l}\text { Results from this } \\
\text { study indicate a } \\
\text { significant decrease } \\
\text { of IOP after yoga } \\
\text { ocular exercise }\end{array}$ \\
\hline $\begin{array}{l}\text { Satish } \\
\text { Kumar } \\
\text { Gupta, S } \\
\text { Aparna }\end{array}$ & 2020 & $\begin{array}{l}\text { Effect of yoga } \\
\text { ocular } \\
\text { exercises on } \\
\text { eye fatigue }\end{array}$ & $\begin{array}{l}\text { two groups } \\
\text { experimenta } \\
1 \text { design }\end{array}$ & \begin{tabular}{lrr} 
Yoga & \multicolumn{2}{r}{ ocular } \\
exercises for 30 \\
min/day for 5 \\
days/week.
\end{tabular} & $\begin{array}{l}\text { Yoga ocular } \\
\text { exercises reduce the } \\
\text { eye fatigue } \\
\text { symptoms score by } \\
\text { increasing } \\
\text { the efficiency of } \\
\text { extraocular } \\
\text { muscles. }\end{array}$ \\
\hline $\begin{array}{l}\text { Misbakhul } \\
\text { Anwari, } \\
\text { Rita, } \\
\text { Ropickhotu } \\
\text { s Salamah, } \\
\text { Mashila } \\
\text { Refani, Nur } \\
\text { Winingsih, } \\
\text { Dwi Yoga, } \\
\text { Rizka Inna, } \\
\text { Tantut } \\
\text { Susanto }\end{array}$ & 2018 & $\begin{array}{l}\text { Eye Gesture } \\
\text { Training For } \\
\text { Eye Health: } \\
\text { Case Study } \\
\text { On Family } \\
\text { Home } \\
\text { Care In } \\
\text { Kemuningsari } \\
\text { Lor Village, } \\
\text { Panti, Jember }\end{array}$ & $\begin{array}{l}\text { Case study: } \\
\text { pretest and } \\
\text { posttest } \\
\text { design }\end{array}$ & $\begin{array}{l}\text { Eye movements } \\
\text { carried out for } \pm 5 \\
\text { minutes. Motion } \\
\text { training } \\
\text { consists of } r \\
\text { movements }\end{array}$ & $\begin{array}{l}\text { There is a } \\
\text { Significant impact } \\
\text { between } \\
\text { movement } \\
\text { exercises on eye } \\
\text { health and being } \\
\text { able to improve } \\
\text { vision / eye acuity. }\end{array}$ \\
\hline $\begin{array}{l}\text { Ratna Indah } \\
\text { Sari Dewi, } \\
\text { Vino Rika } \\
\text { Novia }\end{array}$ & 2020 & $\begin{array}{l}\text { Pengaruh } \\
\text { Senam Yoga } \\
\text { Mata } \\
\text { Terhadap } \\
\text { Penurunankel } \\
\text { elahan Mata } \\
\text { Pada Pekerja } \\
\text { Di Divisi } \\
\text { Redaksi } \\
\text { Padang } \\
\text { Ekspres }\end{array}$ & $\begin{array}{l}\text { One Group } \\
\text { pretest } \\
\text { posttest }\end{array}$ & $\begin{array}{ll}\text { yoga } & \text { ocular, } \\
\text { gymnastics } & \\
\text { performed in } 12 \\
\text { movements with a } \\
\text { duration of } 15 \\
\text { seconds } \\
\text { movement. }\end{array}$ & $\begin{array}{l}\text { In this study, it was } \\
\text { found that the } \\
\text { positive effect of } \\
\text { eye yoga exercises } \\
\text { on eye fatigue in } \\
\text { computer user } \\
\text { workers }\end{array}$ \\
\hline $\begin{array}{l}\text { Sang-Dol } \\
\text { Kim }\end{array}$ & 2016 & $\begin{array}{lr}\text { Effects } & \text { of } \\
\text { yogic } & \text { eye } \\
\text { exercises } & \text { on }\end{array}$ & $\begin{array}{l}\text { pretest-postt } \\
\text { est design } \\
\text { with } \quad \text { a }\end{array}$ & $\begin{array}{l}\text { Yogic exercises } \\
\text { were conducted for } \\
\text { about one hour per }\end{array}$ & $\begin{array}{l}\text { yogic eye exercises } \\
\text { could reduce the } \\
\text { eye fatigue score in }\end{array}$ \\
\hline
\end{tabular}




\begin{tabular}{|c|c|c|c|c|c|}
\hline & & $\begin{array}{l}\text { eye fatigue in } \\
\text { undergraduat } \\
\text { e nursing } \\
\text { students }\end{array}$ & $\begin{array}{l}\text { non-equival } \\
\text { ent control } \\
\text { group }\end{array}$ & $\begin{array}{l}\text { session, twice a } \\
\text { week for } 8 \text { weeks }\end{array}$ & $\begin{array}{l}\text { undergraduate } \\
\text { nursing students }\end{array}$ \\
\hline $\begin{array}{l}\text { Mujahid K } \\
\text { Sheikh, } \\
\text { Rutuja } \\
\text { Malavde, } \\
\text { Sachin } \\
\text { Daigavane }\end{array}$ & 2020 & $\begin{array}{l}\text { Yogic Eye } \\
\text { Exercises } \\
\text { Followed by } \\
\text { the Ergonomic } \\
\text { Advice on Eye } \\
\text { Fatigue in } \\
\text { Children } \\
\text { Attending } \\
\text { Online Classes } \\
\text { in COVID-19 }\end{array}$ & $\begin{array}{l}\text { randomized } \\
\text { sampling } \\
\text { method }\end{array}$ & $\begin{array}{l}\text { Yogic eye exercises } \\
\text { were conducted for } \\
\text { about one hour per } \\
\text { session, twice a } \\
\text { week for } 4 \text { weeks. } \\
\text { They consisted } \\
\text { of } 8 \text { steps }\end{array}$ & $\begin{array}{l}\text { effect of } \\
\text { self-relaxing yogic } \\
\text { eye exercises } \\
\text { followed by the } \\
\text { ergonomic advice } \\
\text { on eye fatigue in } \\
\text { school-aged } \\
\text { children }\end{array}$ \\
\hline $\begin{array}{l}\text { Naresh } \\
\text { Kumar and } \\
\text { Dr. Nishan } \\
\text { Singh Deol }\end{array}$ & 2017 & $\begin{array}{lr}\text { Effect } & \text { of } \\
\text { selected } & \text { yogic } \\
\text { exercise } & \text { on } \\
\text { males } & \text { visual } \\
\text { acuity } & \end{array}$ & $\begin{array}{l}\text { pretest-postt } \\
\text { est design }\end{array}$ & $\begin{array}{l}\text { yogic training, } \\
\text { consist following } \\
\text { exercises such } \\
\text { as Palming, } \\
\text { Blinking, Sideways } \\
\text { viewing, Front and } \\
\text { Sideways viewing, } \\
\text { Rotational viewing, } \\
\text { Up and down } \\
\text { viewing, Near \& } \\
\text { distant viewing etc }\end{array}$ & $\begin{array}{l}\text { There is significant } \\
\text { differences were } \\
\text { observed between } \\
\text { pre and post-test of } \\
\text { visual acuity of } \\
\text { right eye }\end{array}$ \\
\hline
\end{tabular}

Based on the literature review of 8 major journals (table 1), it was found that ocular exercise yoga increased vergency and was considered a therapeutic and non-pharmacological intervention for eye fatigue. The duration of each study has a different time, the stages of implementation have a different number of steps, but have content in the stages carried out in ocular yoga such as palming, blinking, sideways viewing, forward and sideways viewing, diagonal viewing, rotational viewing, preliminary nose-ends. stare, see near and far, gaze concentrated, and the acupressure point on the palm. The eight journals analyzed showed a positive impact in overcoming eye fatigue by revitalizing and relaxing muscles, preventing and correcting squints, improving medial and lateral muscle coordination, restoring balance to muscles around the eyes and increasing coordinated activity of the eyeballs. So it can be stated that 8 journals state that ocular yoga can reduce the incidence of eye fatigue caused by prolonged exposure to gadgets.

\section{DISCUSSION}

Covid-19 pandemic has caused a lot of chaos in many countries, especially since the imposition of quarantine (lockdown) in some countries or travel restrictions. In Indonesia, the Government did not take a decision to lock down, but instead determined a "Public Health Emergency Status" by implementing Large-Scale Social Restrictions / Pembatasan Sosial Berskala Besar (PSBB) at the entrance. This policy stipulates the application of an online learning system and work system(Mulyadi, Prabowo, Salve, \& Ayuningsih, 2020). These circumstances lead to use of computers, laptops, tablets, and smartphones have been seen increasing in recent months. This digital device requires holding at a distance between close and visibility, causing the visual system, designed for comfortable near and far vision. remote-system policies during the COVID-19 pandemic are immediately improving the amount of time spent using the gadget (Balasopoulou et al., 2017b). 
Using gadgets for a long time causes disruption of the eye muscles and even causes problems that are often felt but not realized by most people (Munsamy \& Chetty, 2020). The main function of the eye muscles is an apparatus for implementing eye movements. The muscles that take up the eye, control many of the various eye movements. In fact, these muscles are small and not very strong, helping the eye to perform many complex tasks, including moving objects, scanning objects and maintaining a stable image on the retina. For this reason, the appearance of muscle problems makes vision difficult to focus and can cause pain. Using a computer for a long time can cause the negative symptoms to the eye muscles. Hence, it is important to reduce the eyes fatigue and also to monitor the eye muscles working more efficiently and effectively (Sheikh et al., 2020).

Yoga ocular exercises are believed to increase eye motility and help reduce eye fatigue by improving binocular vision function related to accommodation and vergence (Gupta \& Aparna, 2019). According to research, eye movement exercises are significant to changes in eye fatigue, eye sharpness and relax eye muscle tension. It also revealed that eye movement exercise is an effort that can be done to improve eye health at all ages because this action does not have a bad effect on the eyes (Anwari et al., 2018).

\section{Procedure of Yoga Ocular}

Each ocular yoga practice session involves the following steps in sequence: palming, blinking, sideways viewing, forward and sideways viewing, diagonal viewing, rotation viewing, preliminary nose-tip gazing, near and distant viewing, concentrated gazing, and acupressure point on the palm. Subjects in the exercise group did the exercise for 25-30 minutes an average of 5 days / week.

1. Eye movement

The first technique is aimed at increasing flexibility and strengthening the muscles around the eyes, then making movements in all directions on the eye, repeating 6-8x each. Breathe deep. We can see figure 1 for the eye movement.

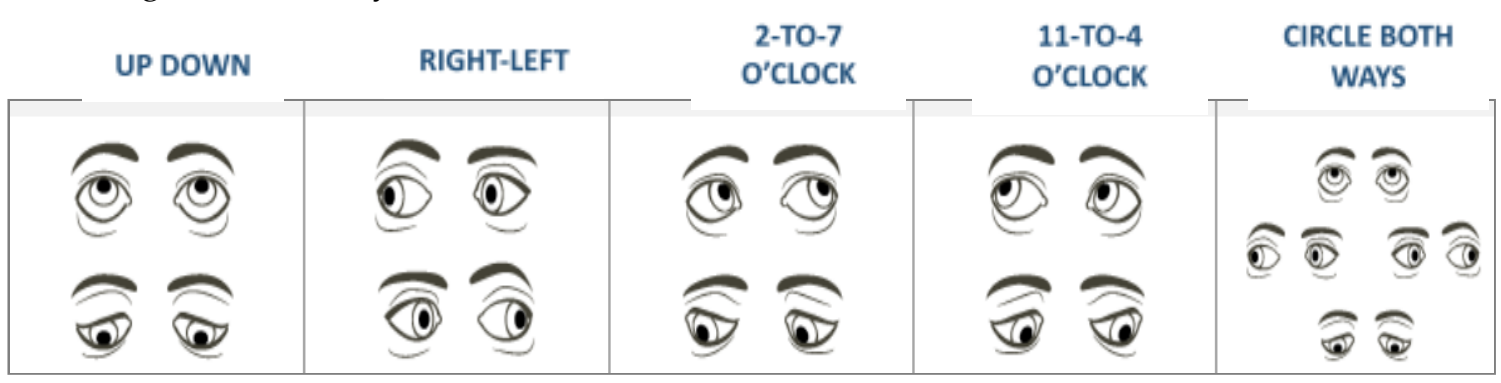

Figure 1. Eye Movement

2. Eye focusing

Shift your eyes from close to far and back. Repeat 6-8x each. Take a deep breath. Details about eye focusing is in presented in figure 2 .

NEAR-FAR

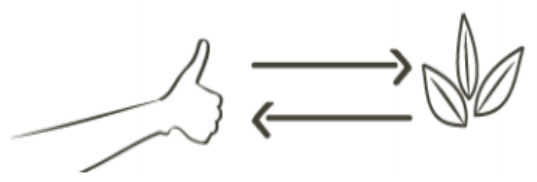

Shift the gaze from the thumb of your extended hand to some object at a distance and back.
FOLLOW THE TUMB

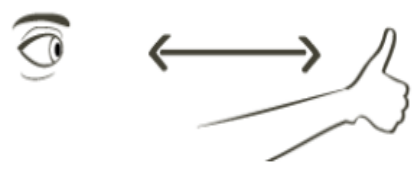

Look at your thumb. Slowly move it closer to your nose and then away from it.

3. Palming

Figure 2. Eye focusing in Yoga Ocular exercise 
This exercise creates relaxation which amplifies other effects. palming serves to relax the optic nerve, relax the nervous system, and improves circulation to eyes. The passive experience breaks your eye while you are asleep and is not enough to fully relax them. the eye requires active, conscious relaxation that comes by palming. palming is done by rubbing the palms together until they are warm, then covering the eyes with the palms for a few minutes. The results of palming differ greatly from individual to individuals, but doing palming has a good enough advantage to relax the eyes.

4. Blinking

This simple but powerful exercise, bathes and massage both eyes, removing both eyes from focusing work to close vision, and reduces tension around the eyes. Most people with poor eyesight have lost their ability to blink easily and frequently. This blinking exercise will help relax your crossed eyes and frees the view to move smoothly from one object to another. Breathe deeply. Start slowly, open gently and close your eyes then blink alternately, when the right eye is closed, the envious eye is blinked. Feel the forehead to make sure it doesn't frown. If the forehead doesn't move, it means the blink is relaxed. Massage your forehead over the left and right eye alternately with the fingers.

5. Shifting

Normal eyes make lots of small movements. This is known as the saccadic movement, The purpose of the saccadic movement is to get involved in macula - the part of the eye that is responsible for sharp and detailed vision.Shifting is designed to restore nature free movement of the macula. As the name implies, all of these exercises involve shifting focus point from one place to another, mimicking a normal saccadic movement.

6. Sunning

Sunning is the main exercise to train the eyes to receive sunlight after spending most of our life indoors.Sit or stand outside or in an open window (remember: never penetrate the glass). close your eyes Facing the sun, move your head from side to side, bringing the chin towards shoulder before moving on to the other. Then take a deep, slow breath.

7. Skying

The purpose of skying is similar to sunning: to teach the eyes and brain to receive light comfortably, without feeling tense(Smellie, 2016).

\section{Effectiveness on Eye Fatigue}

During ocular yoga practice, the bulbomotor muscles are maximally and continuously stretched in any direction which improves intra-orbital blood circulation and can also act as a pump for more efficient intra-orbital venous outflow. 'Palming' may have a vasodilating effect for chronic venous episodes and thereby aqueous outflow (Dimitrova \& Trenceva, 2017). Yoga ocular exercises can be referred to as isotonic / dynamic EOMs (skeletal muscle) exercises, where there are concentric contractions (shortening) and eccentric contractions (extensions) of the extraocular muscles (EOMs). Regular skeletal muscle training trains them to perform more efficiently(Gupta \& Aparna, $2019 \mathrm{a}, \mathrm{b}$ ) (Kumar \& Deol, 2018). The benefits of each ocular yoga practice are described as follows: revitalizes the eye muscles, relaxes muscle tension, prevents and corrects squints, improves medial and lateral muscle coordination, restores balance to the muscles around the eyes and improves coordinated activity of the two eyeballs, balances the eyeball muscles. up and down, increases the accommodating power and focusing of the eye muscles, and increases the range of motion (Munsamy \& Chetty, 2020, Sheikh et al., 2020).

In others' study, it was explained that the eye fatigue score and intraocular pressure (IOP) were reduced after doing ocular yoga. The study reported that IOP decreased significantly and the mean retinal thickness of the macula increased significantly after yoga practice for eyes in healthy controls (Galina, D.et.al, 2020). Eye exercises (ocular yoga) have been recognized to improve a wide variety of conditions including vergence problems, ocular motility disorders, asthenopia, myopia, accommodative dysfunction, amblyopia, stereopsis, visual field defects, visual acuity, and general 
well-being. The trials in this study were less robust, but it is credible that visual training may be useful in developing fine stereoscopic skills and improving visual health after brain (Rawstron, et al.,(2020). Ocular yoga is also effective in overcoming eye fatigue, in a study it was explained that computer users experienced a decrease in eye fatigue after doing yoga, this was evidenced by a decrease in the level of eye fatigue from 4.75 to 1.94 (Novia, 2018).

\section{CONCLUSION}

Yoga ocular exercises reduce eye fatigue and affect vergencer-related binocular vision function improvement by enhancing efficiency of eye motility muscles, this exercise reduces the prevalence and incidence of eye fatigue. Therefore, based on the 8 main journals, all of them provide the positive effects after doing ocular yoga, it confirms that yoga ocular exercises can be considered as a therapeutic and nonpharmacological intervention to reduce asthenopic symptoms as well as relieve the severity of eye fatigue. The provision of yoga ocular therapy is only recommended for minor eye health problems, this exercise also has no side effects on its users, so that this intervention can be used to maintain eye health in the new normal era.

\section{REFERENCE}

Anwari, M., Vidyawati, R., Salamah, R., Refani, M., Winingsih, N., Yoga, D., ... Susanto, T. (2018). Latihan Gerak Mata Untuk Kesehatan Mata: Studi Kasus Pada Keluarga Binaan Di Desa Kemuningsari Lor Kecamatan Panti Kabupaten Jember. The Indonesian Journal of Health Science, 155. https://doi.org/10.32528/ijhs.v0i0.1540

Balasopoulos, A., Kokkinos, P., Pagoulatos, D., Plotas, P., Makri, O. E., Georgakopoulos, C. D., ... Loukovaara, S. (2017a). Digital eye strain in the era of COVID-19 pandemic: An emerging public health threat. BMC Ophthalmology, 17(1), 1. https://doi.org/10.4103/ijo.IJO

Balasopoulos, A., Kokkinos, P., Pagoulatos, D., Plotas, P., Makri, O. E., Georgakopoulos, C. D., ... Loukovaara, S. (2017b). Impact of the COVID-19 lockdown on digital device-related ocular health. BMC Ophthalmology, 17(1), 1. https://doi.org/10.4103/ijo.IJO

Dimitrova, G., \& Trenceva, A. (2017). The short-term effect of yoga ocular exercise on intraocular pressure. Acta Ophthalmologica, 95(1), e81-e82. https://doi.org/10.1111/aos.12850

Gupta, S., \& Aparna, S. (2019). Effect of yoga ocular exercises on eye fatigue. Yoga Mimamsa, 51(2), 48. https://doi.org/10.4103/ym.ym_13_19

Galina, D., et al. 2020. Immediate effect of Yoga exercises for eyes on the macular thickness

Kim, S. D. (2016). Effects of yogic eye exercises on eye fatigue in undergraduate nursing students. Journal of Physical Therapy Science, 28(6), 1813-1815. https://doi.org/10.1589/jpts.28.1813

Kumar, N., \& Deol, N. S. (2018). Effect of selected yogic exercise on males visual acuity. 3(1), 832-834.

Mulyadi, S., Prabowo, H., Salve, H. R., \& Ayuningsih, A. M. (2020). Sleep Duration, Internet Use Duration and Anxiety on University Student during Covid-19 Pandemic. 2199-2209.

Munsamy, A., \& Chetty, V. (2020). Digital eye syndrome: COVID-19. S Afr Med J, 1(May), 14906.

Novia, V. R. (2018). Pengaruh senam yoga mata terhadap penurunan kelelahan mata pada pekerja di divisi redaksi padang ekspres 1,2.

Puspa, A. K., Loebis, R., \& Nuswantoro, D. (2018). Pengaruh Penggunaan Gadget terhadap Penurunan Kualitas Penglihatan Siswa Sekolah Dasar The Using of Gadget and Its Effect of Decreasing the Quality of Vision in Elementary School Students. 6(47), 28-33.

Rawstron, J. A., Burley, C. D., \& Elder, M. J. (2020). A systematic review of the applicability and efficacy of eye exercises. Journal of pediatric ophthalmology and strabismus, 42(2), 82-88.https://doi.org/10.3928/01913913-20050301-02

Sheikh, M. K., Malavde, R., \& Daigavane, S. (2020). Yogic eye exercises followed by the ergonomic advice on eye fatigue in children attending online classes in COVID-19. International Journal of Current Research and Review, 12(17), 132-136. https://doi.org/10.31782/IJCRR.2020.121720 
Smellie, A. (2016). Yoga for Your Eyes! In Daily Mail. Retrieved from http://search.ebscohost.com/login.aspx?direct=true\&db=bwh\&AN=115419426\&lang=zh-cn\&site= ehost-live 